JURNAL KETAHANAN NASIONAL

Vol. 25, No. 3, Desember 2019, Hal 313-312

DOI:http://dx.doi.org/ 10.22146/jkn.49528

ISSN:0853-9340(Print), ISSN:2527-9688(Online)

Online sejak 28 Desember 2015 di :http://jurnal.ugm.ac.id/JKN

VOLUME 25

No. 3, Desember 2019

Halaman 313-330

\title{
Implementasi Strategi Pengendalian Alur Laut Kepulauan Indonesia (ALKI) II Dalam Mendukung Ketahanan Nasional
}

\author{
Abdiyan Syaiful Hidayat \\ Seskoal/ TNI Angkatan Laut \\ email: abdiyansyaiful_hidayat@tnial.mil.id \\ Asep Iwa Soemantri \\ Seskoal/ TNI Angkatan Laut \\ email: asepiwasoemantri@yahoo.com \\ Hariyo Poernomo \\ Seskoal/ TNI Angkatan Laut \\ email: hariyo.anaklaut@protonmail.com
}

\begin{abstract}
The Republic of Indonesia had ratified the UNCLOS 82 through the Indonesian Law No. 17 of 1985 dated 13 December 1985, which was in force on 16 November 1994. As a result, Indonesia had established three archipelagic sea lanes, or otherwise known as ALKI, namely ALKI I, ALKI II and ALKI III. With this establishment, Indonesia as the archipelagic state must be capable of ensuring safe passage of shipping through these lanes, while at the same time capable of enforcing its sovereignty over the related waters to support Indonesian National Resillience. The purpose of this study was to analyzed the various determinant factors which affected the Indonesian Navy's Second Fleet Command's success in implementing sea control strategy within ALKI II. These factors were tactics and procedures, weaponry capability, sensors capability, exercise and operational effectiveness.

The research was conducted using mixed research methods. The determinant factor would be established in a statistic model which named Structural Equation Modeling which used the Lisrel software version 8,70.

The result showed that five hypothesis were accepted and six parameters of goodness of fit are suitable. The end results of this research concluded that tactics and procedures, weaponry capability, sensors capability and exercise affected operational effectiveness. In addition, operational effectiveness would affect the Second Fleet Command's ability to implement and executed the sea control strategy successfully required for sustaining national resillience.
\end{abstract}

Keywords: Sea Control, Indonesia Archipelagic Sea Lane, Structural Equation Modeling.

\begin{abstract}
ABSTRAK
Indonesia telah meratifikasi UNCLOS 1982 melalui Undang-undang Nomor 17 Tahun 1985 tanggal 13 Desember 1985 dan mulai berlaku pada tanggal 16 November 1994. Sebagai konsekuensinya Indonesia menetapkan tiga jalur Alur Laut Kepulauan Indonesia (ALKI), yaitu ALKI I, ALKI II dan ALKI III. Untuk itu Indonesia harus dapat menjamin keamanan pelayaran di sepanjang ALKI dan menegakkan kedaulatan untuk mendukung ketahanan nasional Indonesia. Tujuan penelitian ini untuk mengidentifikasi dan memodelkan faktor-faktor yang mempengaruhi keberhasilan Komando Armada (Koarmada) II dalam mengimplementasikan strategi pengendalian laut di ALKI II. Faktor-faktor yang digunakan dalam penelitian ini adalah penguasaan taktik dan prosedur, kemampuan persenjataan, kemampuan sensor dan latihan untuk meningkatkan efektivitas operasi.
\end{abstract}


Penelitian menggunakan metode penelitian campuran. Pemodelan faktor-faktor dilakukan dengan metode Structural Equation Modeling (SEM) dengan software Lisrel versi 8,70.

Hasil penelitian menunjukkan bahwa lima hipotesis penelitian dapat diterima dan enam parameter goodness of fit memiliki kecocokan yang baik. Model penelitian cukup fit dan diperoleh kesimpulan bahwa penguasaan taktik dan prosedur, kemampuan persenjataan, kemampuan sensor dan latihan berpengaruh positif dan signifikan terhadap efektivitas operasi, serta efektivitas operasi berpengaruh secara positif dan signifikan terhadap keberhasilan Koarmada II dalam mengimplementasikan strategi pengendalian laut di ALKI II yang diperlukan dalam menopang ketahanan nasional.

\section{Kata Kunci: Pengendalian Laut, Alur Laut Kepulauan Indonesia, Structural Equation Modeling.}

\section{PENGANTAR}

Ketahanan nasional mengandung makna adanya kondisi dinamis suatu bangsa, berisikan keuletan dan ketangguhan, yang membentuk kekuatan nasional yang mampu menghadapi dan mengatasi setiap macam ancaman, tantangan, hambatan dan gangguan baik yang datang dari luar maupun dari dalam negeri secara langsung atau tidak langsung membahayakan kelangsungan hidup bangsa serta pencapaian tujuan nasionalnya (Suryohadiprojo, 1997:14). Kondisi dinamis tersebut mencakup seluruh aspek kehidupan bangsa baik alamiah maupun sosial termasuk geostrategi Indonesia dalam penguatan keamanan maritim. Indonesia adalah negara kepulauan terbesar di dunia, dengan wilayah yang didominasi oleh laut, sehingga keamanan maritim menjadi prasyarat bagi berlangsungnya pembangunan nasional. Tanpa stabilitas keamanan maritim, berbagai aktivitas usaha tidak akan berjalan dengan baik, dan sebagai akibatnya perputaran roda ekonomi dan pembangunan nasional akan terhambat. Dengan demikian dapat dikatakan bahwa untuk Indonesia, keamanan maritim adalah salah satu kunci keberlangsungan hidup bangsa dan negara.

Indonesia mendapat pengakuan sebagai negara kepulauan yang merupakan bagian integral hukum laut internasional pada tanggal 10 Desember 1982 melalui Konvensi yang dinamakan United Nation Convention On The Law Of The sea atau dikenal dengan UNCLOS 1982. Sebagai konsekuensinya Indonesia tunduk dan terikat pada hak dan kewajiban sesuai ketentuan pasal-pasal pada konvensi tersebut, yaitu dengan menetapkan alur laut kepulauan bagi kapal dan pesawat udara asing dengan tetap mematuhi rejim laut yang dilewati sebagaimana diatur dalam pasal 53 UNCLOS 1982. Indonesia telah menetapkan 3 (tiga) buah ALKI, yakni ALKI I, melalui laut Cina Selatan, Selat Karimata, Selat Sunda ke Samudra Hindia. ALKI II, melalui Laut Sulawesi, Selat Makassar, Selat Lombok menuju Samudra Hindia, dan ALKI III, melalui Laut Maluku, Laut Sunda, yang sebelah selatan bercabang tiga ke Laut Sawu menuju Samudra Hindia, ke Laut Arafura menuju Samudra Hindia dan sebelah timur Pulau Timor menuju Samudra Hindia (Djalal, 2010:123).

Penetapan tiga ALKI yang mengatur hak lintas bagi kapal dan pesawat udara asing yang akan melalui perairan kepulauan Indonesia, pada hakekatnya merupakan bentuk penyederhanaan dari begitu luas dan banyaknya pintu-pintu masuk ke wilayah Indonesia. Pintu masuk dan keluar yang terpusat di tiga ALKI tersebut berdampak pada timbulnya berbagai potensi ancaman antara lain pelanggaran wilayah yang berkaitan dengan batas wilayah atau kedaulatan oleh negara 
asing, kegiatan penyelundupan, kejahatan antar negara, terorisme dan lain sebagainya. Akibat dari pelanggaran yang terjadi bukan hanya kerugian material yang ditimbulkan bahkan apabila hal ini dibiarkan terus menerus dan tidak segera ditangani akan dapat mempengaruhi stabilitas keamanan nasional sehingga ketahanan nasional terganggu. Oleh karena itu, diperlukan kekuatan TNI Angkatan Laut dalam melaksanakan pengendalian laut.

Pengendalian laut mengandung dua hal pokok yaitu menjamin kelancaran dan keamanan terselenggaranya penggunaan dan pemanfaatan laut bagi kepentingan sendiri atau kawan, serta mencegah penggunaan laut oleh pihak lain yang merugikan kepentingan sendiri. Hakekat pengendalian ALKI pada dasarnya sama dengan hakikat pengendalian laut itu sendiri yaitu untuk menegakkan kedaulatan negara Indonesia di wilayah perairan nasional, yang digunakan untuk lintas internasional (Buntoro, 2017:197). Pengendalian laut di ALKI diarahkan untuk menjaga keamanan negara, keselamatan navigasi, serta keamanan dari berbagai bentuk pelanggaran hukum. Penyelenggaraan pengendalian laut pada masa damai di ALKI dilakukan dengan menghadirkan kekuatan di sepanjang alur laut kepulauan, terutama di titik-titik masuk/keluar, titik belok dan chokepoints yang mencakup dua kegiatan pokok yaitu pengamatan (surveillance) dan penindakan (action). Karakter, bobot serta bentuk kegiatan pengamatan dan penindakan dapat berbeda-beda, tergantung pada tujuan yang ingin dicapai dan ketersediaan sarana untuk mencapai tujuan tersebut (Buntoro, 2017:199).

Komando Armada II (Koarmada II) adalah bagian integral dari TNI Angkatan Laut yang merupakan komponen utama pertahanan negara di laut sesuai dengan ketentuan pada pasal 9 UU RI nomor 34 tahun 2004 memegang peranan utama dan berkewajiban menjaga integritas wilayah NKRI. Koarmada II memiliki peranan penting dalam melaksanakan pengendalian laut di ALKI II sesuai dengan tugas pokok yang diemban dan wilayah kerja yang menjadi tanggung jawabnya. Koarmada II melaksanakan pengendalian laut di ALKI II melalui Komando Tugas Gabungan Pengamanan ALKI II (Kogasgab Pam ALKI II) dengan Pangkoarmada II selaku Panglima Komando Tugas Gabungan (Pangkogasgab) Pengamanan ALKI II. Untuk dapat menjalankan tugasnya, Koarmada II menggelar kekuatan Kapal Republik Indonesia (KRI) dan pesawat udara sebagai sumber daya (means) dalam mengimplementasikan strategi pengendalian laut di ALKI II. Keberhasilan Koarmada II dalam mengimplementasikan strategi pengendalian laut ditentukan oleh beberapa faktor mencakup penguasaan taktik dan prosedur, kesiapsiagaan KRI dan pesawat udara dan latihan sebagai sumber daya (means), efektivitas operasi sebagai cara (ways), serta terjaminnya keamanan di ALKI II sebagai tujuan (ends) yang diukur dari kemampuan monitoring kapal yang melintas di ALKI II, tertanganinya pelanggaran yang terjadi dan daya tangkal yang ditimbulkan.

Teori yang digunakan untuk menganalisis serta mengkaji faktor-faktor yang menentukan keberhasilan pengendalian laut adalah teori strategi oleh Andrew J. Good Paster bahwa strategi adalah adalah ilmu dan seni/cara (ways) bagaimana menggunakan sarana/ potensi (means) yang tersedia untuk mencapai sasaran (ends) yang telah ditentukan (Nelson, 2016:34). Faktor penentu keberhasilan dalam pengendalian laut diurai menggunakan teori pengendalian laut oleh Milan Vego tentang 
prasarat keberhasilan pengendalian laut di antaranya pangkalan strategis, jumlah dan kualitas persenjataan, taktik dan prosedur, latihan, kerja sama, superioritas informasi, serta komando dan kendali (Vego, 2016:61). Selain itu, teori manajemen sumber daya manusia juga digunakan berkaitan dengan penggunaan manusia sebagai sumber daya militer esensial, karena hanya dengan manusia berkualitas dan memiliki motivasi akan mentransformasi anggaran dan persenjataan menjadi kemampuan yang efektif (Marcu, dkk., 2009:125)

Metode penelitian yang digunakan dalam penelitian ini adalah metode campuran (mixed method) yang merupakan campuran antara metode kuantitatif dan kualitatif. Pada tahap awal peneliti melaksanakan identifikasi terhadap teori-teori yang ada untuk menentukan faktor-faktor/variabel-variabel determinan keberhasilan Koarmada II, kemudian faktorfaktor tersebut disusun dalam suatu model dengan menggunakan Structural Equation Modelling (Hidayat, 2019:75). Structural Equation Modelling (SEM) adalah teknik permodelan statistik untuk menguji hubungan antara variabel yang kompleks baik recursive maupun non-recursive dengan tujuan untuk memperoleh gambaran secara menyeluruh mengenai suatu model yang digunakan dalam menyelesaikan suatu masalah (Marlina, 2009:16). Selanjutnya, peneliti menganalisis model yang dibentuk untuk mengetahui tingkatan-tingkatan pengaruh dari variabelvariabel yang diteliti. Analisis data kualitatif dari hasil wawancara mendalam menggunakan Soft System Methodology (SSM).

\section{PEMBAHASAN}

ALKI merupakan konsekuensi Indonesia sebagai negara kepulauan setelah pemerintah Indonesia meratifikasi Hukum Laut Internasional UNCLOS 1982 melalui Undang-Undang RI Nomor 17 Tahun 1985 (Sobaruddin, 2017:105). TNI Angkatan laut sebagaimana Angkatan laut negara lain memiliki tugas universal yakni menegakkan penguasaan atas laut tertentu, mencegah musuh menguasai laut tertentu dan memanfaatkan laut untuk kepentingan sendiri (Wahyono, 1996:23). Oleh karena itu, Koarmada II sebagai bagian integral TNI Angkatan Laut melaksanakan pengendalian laut di ALKI II melalui gelar operasi pengamanan ALKI II dalam sebuah Komando Tugas Gabungan (Kogasgab) yang melibatkan Komando Operasi Angkatan Udara II. Kogasgab Pam ALKI II secara terus menerus berupaya untuk mencegah dan menangkal setiap bentuk tindak pidana dan kejahatan di sepanjang ALKI II dengan menggelar unsur dalam suatu operasi pada titik-titik yang dianggap rawan terjadinya tindak pelanggaran.

Koarmada II melaksanakan pengendalian laut di ALKI II yang mencakup Selat Lombok, Selat Makasar, Laut Sulawesi, serta wilayah perbatasan laut antara Indonesia dengan Malaysia dan Filipina yang menyimpan kerawanan terjadinya berbagai pelanggaran di laut seperti pelanggaran pelayaran, perompakan, penyelundupan, perikanan dan pelanggaran lainnya. Dalam implementasi strategi pengendalian laut tidak terlepas dari taktik dan prosedur, kemampuan senjata, kemampuan sensor dan latihan sebagai sumber daya (means), efektivitas operasi sebagai (ways), serta terjaminnya keamanan di ALKI II sebagai tujuan (ends).

Metode penelitian yang digunakan adalah metode campuran (mixed method) antara kuantitatif dengan kualitatif. Metode campuran metode yang memanfaatkan 
kekuatan metode kuantitatif dan kualitatif sekaligus (Cresswell, 2016:288). Varian yang dipilih adalah penelitian campuran konkuren/ satu waktu (concurrent mixed method) dengan bobot metode kuantitatif lebih tinggi dari pada kualitatif. Penelitian dilaksanakan dengan survei dan bentuk pengujiannya dengan explanatory/relationship causal yang menganalisis hubungan antara faktorfaktor yang mempengaruhi keberhasilan implementasi strategi pengendalian laut pada masa damai di ALKI II oleh Koarmada II. Pengumpulan data kuantitatif menggunakan instrument penelitian berupa kuesioner bersifat tertutup selanjutnya pengolahan data menggunakan teknik Struktural Equation Modelling (SEM) untuk menganalisis hubungan antara faktor-faktor yang mempengaruhi keberhasilan implementasi strategi pengendalian laut pada masa damai di ALKI II. Prosedur SEM secara umum melalui pentahapan spesifikasi model, identifikasi model, estimasi parameter dalam model, evaluasi model dan respesifikasi model. Pengambilan data kuantitatif dilaksanakan di Markas Komando Koarmada II di Surabaya, Markas Komando Gugus Keamanan Laut (Guskamla) Koarmada II di Manado, KRI dan pesawat udara yang terkait dengan pengendalian laut di ALKI II dengan populasi sejumlah 815 orang dan sampel sejumlah 277 orang.

Pengumpulan data kualitatif melalui wawancara selanjutnya pengkodingan menggunakan software NVIVO. Analisis data kualitatif mengikuti tahapan Soft System Methodology (SSM). Dalam SSM terdapat tujuh tahap analisis data, yaitu pengidentifikasian masalah, mengekspresikan masalah dengan rich picture, memformulasikan root definition dengan melakukan system thinking, pemodelan sistem, membandingkan hasil analisa dengan keadan di lapangan, analisa inti, dan rekomendasi penyelesaian masalah. Analisis kualitatif diperlukan untuk menguatkan dan menjelaskan hasil dari analisis kuantitatif. Peneliti mewawancarai Asisten Operasi Kepala Staf Angkatan Laut, Komandan Gugus Tempur Laut Koarmada II, Asisten Intelijen Pangkoarmada II, Asisten Operasi Koarmada II, Kepala Pusat komando dan Kendali Koarmada II, Komandan Skuadron 800 dan 600 Pusat Penerbangan TNI Angkatan Laut (Puspenerbal), beberapa Komandan KRI dan pilot pesawat udara yang pernah melaksanakan operasi di ALKI II.

Penelitian menguji hubungan antara faktor-faktor yang mempengaruhi implementasi manajemen pengetahuan. Model penelitian terdiri dari 6 variabel laten dan 46 variabel terukur. Variabel laten meliputi penguasaan taktik dan prosedur (PPM), kemampuan persenjataan (KPM), kemampuan sensor (KSM), latihan (LTM), efektivitas operasi (OPW) dan Keberhasilan Strategi/end (END). Pengukururan keenam variabel tersebut menggunakan instrumen pengukur yang berupa pernyataan dari masingmasing indikator untuk tiap-tiap variabel yang diajukan kepada responden melalui kuesioner. Dalam penelitian ini menggunakan pernyataan yang selanjutnya dianalisis secara kuantitatif dengan menggunakan Skala Likert. Variabel laten dalam penelitian ini dapat diklasifikasikan menjadi variabel eksogen yaitu PPM, KPM, KSM dan LTM, serta variabel endogen. Terdapat dua jenis variabel endogen yaitu variabel endogen intervening adalah OPW dan variabel endogen tergantung adalah END. Model penelitian implementasi strategi pengendalian laut ditunjukkan pada gambar 1. 
Gambar 1

Model Penelitian

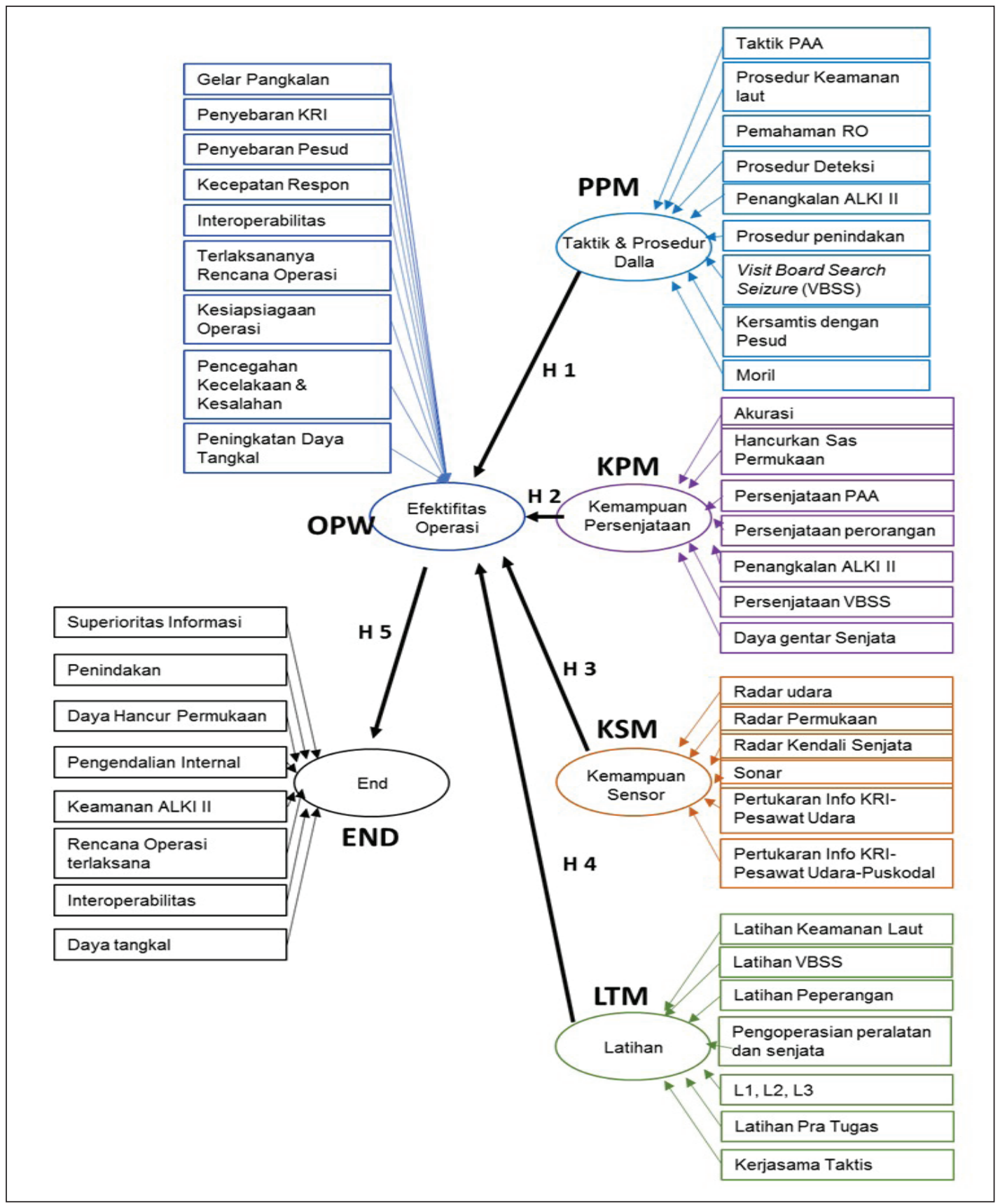

Sumber: Data primer dan sekunder diolah, 2019.

Gambar 1 menunjukkan bahwa penelitian ini menguji lima hipotesis. Hipotesis pertama, penguasaan taktik dan prosedur pengendalian laut mempengaruhi secara positif dan signifikan terhadap efektivitas operasi dalam mendukung keberhasilan Koarmada II dalam mengimplementasikan strategi pengendalian laut di ALKI II. Hipotesis kedua, kemampuan persenjataan KRI memiliki pengaruh yang positif dan signifikan terhadap efektivitas operasi guna mendukung keberhasilan Koarmada II dalam mengimplementasikan strategi pengendalian laut di ALKI II. Hipotesis ketiga, kemampuan 
peralatan penginderaan/sensor KRI dan pesawat udara memiliki pengaruh yang positif dan signifikan terhadap efektivitas operasi guna mendukung keberhasilan Koarmada II dalam mengimplementasikan strategi pengendalian laut di ALKI II. Hipotesis keempat, kuantitas dan kualitas latihan mempengaruhi secara positif dan sigifikan terhadap efektivitas operasi guna mendukung keberhasilan Koarmada II dalam mengimplementasikan strategi pengendalian laut di ALKI II. Hipotesis kelima, efektivitas operasi memiliki pengaruh yang positif dan signifikan terhadap keberhasilan Koarmada II dalam mengimplementasikan strategi pengendalian laut di ALKI II.

Pengumpulan data kuantitatif melalui pendistribusian kuesioner kepada personel satuan kerja Markas Komando Koarmada II, Guskamla Koarmada II, KRI dan pesawat udara yang melaksanakan operasi di ALKI II periode 2016 sampai dengan 2018. Data kuesioner yang berhasil dikumpulkan sebanyak 277 responden yang berasal dari level perwira, bintara dan tamtama. Model pengukuran terhadap model penelitian menggunakan data penelitian dengan variabel latent penguasaan taktik dan prosedur (PPM), kemampuan persenjataan (KPM), kemampuan sensor (KSM), kuantitas dan kualitas latihan (LTM), efektivitas operasi (OPW), serta keberhasilan strategi pengendalian laut (END). Estimasi terhadap model pengukuran dari Model Penelitian dengan menggunakan data penelitian memberikan hasil seperti yang ditunjukkan oleh diagram lintasan pada gambar 2.

Tahap estimasi menghasilkan solusi yang berisi nilai akhir dari parameter-parameter yang diestimasi. Dalam tahap ini peneliti memeriksa tingkat kecocokan antara data dengan model. Evalusi terhadap tingkat kecocokan data dengan model dilakukan dengan beberapa tahapan, tahapan pertama adalah uji kecocokan keseluruhan model. uji kecocokan model pengukuran dan uji kecocokan model struktural. Hasil perhitungan pengujian kecocokan keseluruhan model dapat dilihat pada tabel 1 .

Hasil uji tersebut menujukkan terdapat 6 ukuran Goodness of Fit Index (GFI) menunjukkan kecocokan yang baik (good fit) dan 3 ukuran GFI lainnya menunjukkan kecocokan yang kurang baik, maka dapat disimpulkan bahwa model yang digunakan dalam penelitian ini dapat dijadikan dasar analisis terhadap permasalahan penelitian. Beberapa kecocokan kurang baik menunjukkan

Tabel 1

Uji Kecocokan Keseluruhan Model

\begin{tabular}{llccc}
\hline \multirow{2}{*}{ Indikator GFI } & \multicolumn{1}{c}{ Keterangan Indikator GFI } & $\begin{array}{c}\text { Nilai Standar } \\
\text { Kecocokan Baik }\end{array}$ & $\begin{array}{c}\text { Hasil } \\
\text { Hitung }\end{array}$ & Kesimpulan \\
\hline RMSEA & Root Mean Square Error of Approximation & $\leq 0,08$ & 0,11 & Kecocokan kurang baik \\
NFI & Normed Fit Index & $\geq 0,90$ & 0,95 & Kecocokan baik \\
NNFI & Non-Normed Fit Index & $\geq 0,90$ & 0,96 & Kecocokan baik \\
CFI & Comparative Fit Index & $\geq 0,90$ & 0,96 & Kecocokan baik \\
IFI & Incremental Fit Index & $\geq 0,90$ & 0,96 & Kecocokan baik \\
RFI & Relative Fit Index & $>0,90$ & 0,95 & Kecocokan baik \\
Std. RMR & Standardized Root Mean Square Residual & $\leq 0,05$ & 0,045 & Kecocokan baik \\
GFI & Goodness of Fit Index & $\geq 0,90$ & 0,62 & Kecocokan kurang baik \\
AGFI & Adjusted Goodness of Fit Index & $\geq 0,90$ & 0,58 & Kecocokan kurang baik \\
\hline
\end{tabular}

Sumber: Data primer diolah, 2019 
Gambar 2

Model Pengukuran Model Penelitian

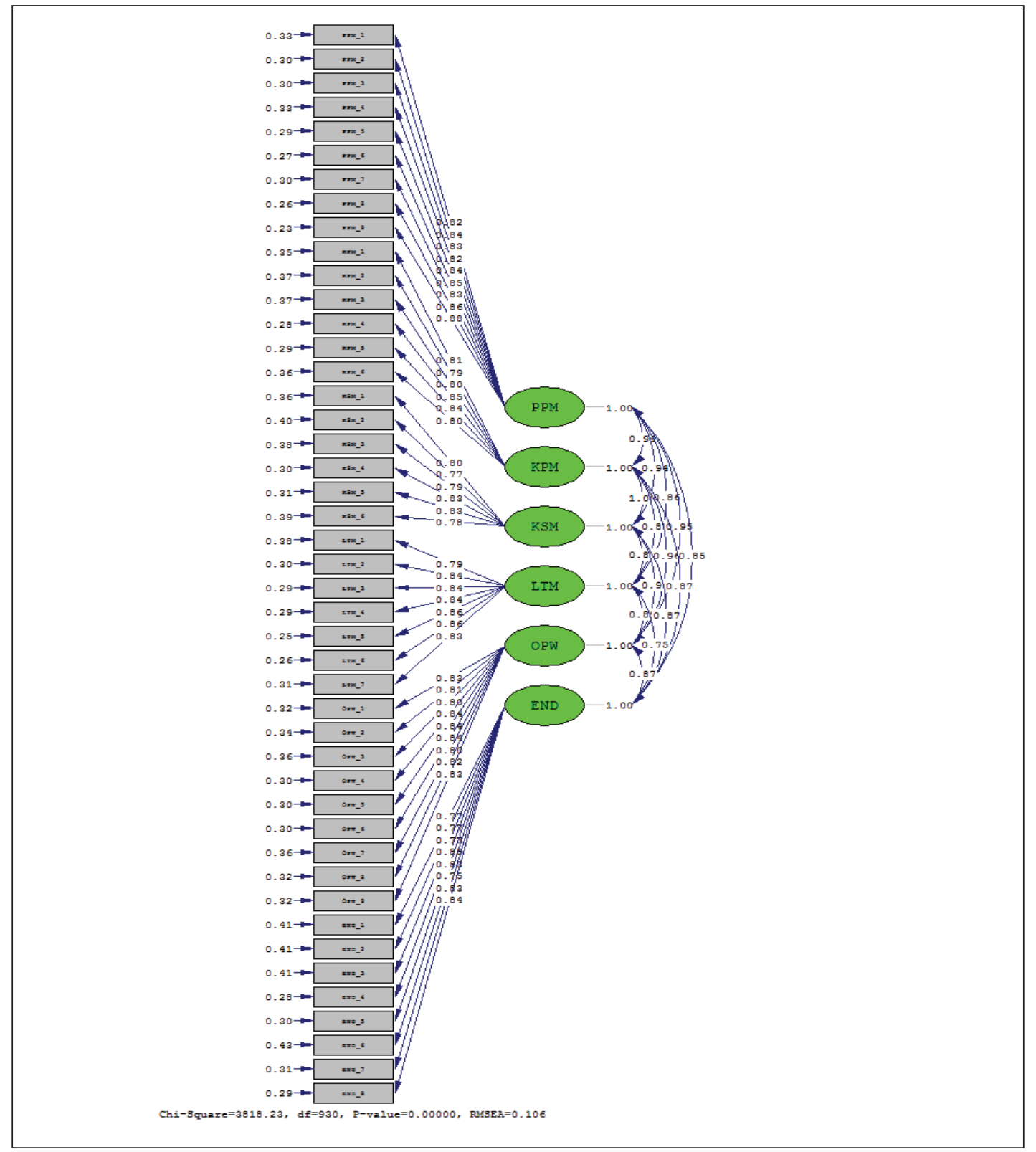

Sumber: Data primer diolah, 2019

adanya variabel-variabel lain yang turut menentukan keberhasilan pengendalian laut yang tidak termasuk dalam penelitian ini. Setelah kecocokan model dan data secara keseluruhan adalah baik, maka langkah berikutnya adalah analisis model struktural menghasilkan path diagram standartdized solution pada gambar 3 , serta path diagram $t$-value pada gambar 4 .
Analisis model struktural terhadap gambar 3 dan gambar 4 berkaitan dengan uji hipotesis-hipotesis penelitian. Hipotesis penelitian diterima jika angka absolut nilai $\mathrm{t}$ $>$ 1,96 dengan tanda koefisien sesuai dengan hipotesis penelitian yang diajukan (positif atau negatif). Hasil analisis persamaan struktural sebagaimana tercantum pada tabel 2. 
Abdiyan Syaiful Hidayat, Asep Iwa Soemantri, Hariyo Poernomo -- Implementasi Strategi Pengendalian Alur Laut Kepulauan Indonesia (ALKI) II Dalam Mendukung Ketahanan Nasional

Gambar 3

Diagram Lintasan Model Struktural Penelitian (standard solution)

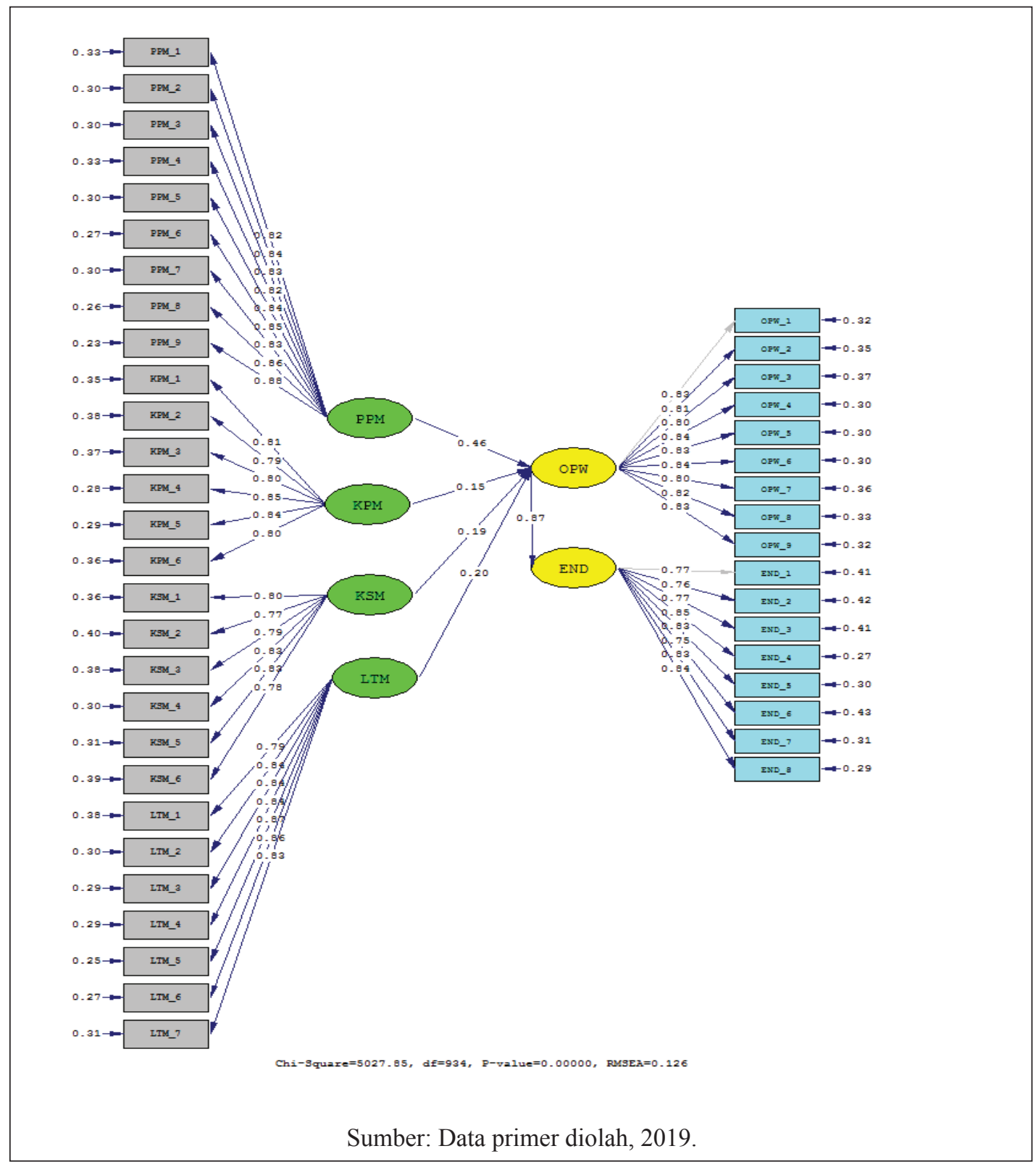

Tabel 2

Hasil Analisis Persamaan Struktural

\begin{tabular}{cccc}
\hline Hipotesis & $\begin{array}{c}\text { Standardized } \\
\text { Coefficient }\end{array}$ & $\mathrm{t}$-value & $\begin{array}{c}\text { Kesimpulan } \\
\text { Hasil Uji } \\
\text { Signifikansi }\end{array}$ \\
\hline H1 & 0,46 & 6,03 & Diterima \\
H2 & 0,15 & 3,86 & Diterima \\
H3 & 0,19 & 5,16 & Diterima \\
H4 & 0,19 & 3,91 & Diterima \\
H5 & 0,88 & 13,37 & Diterima \\
\hline
\end{tabular}

Sumber: Data primer diolah, 2019
Pengaruh Penguasaan Taktik Dan Prosedur Pengendalian Laut (PPM) Terhadap Efektivitas Operasi (OPW)

Teori pengendalian laut menyebutkan bahwa penentu keberhasilan pengendalian laut diantaranya adalah efektivitas operasi dengan salah satu syaratnya yakni penguasaan taktik dan prosedur yang merupakan instrument dari doktrin sebagai jembatan antara teori dan 
Gambar 4

Diagram Lintasan Model Struktural Penelitian (T-Values)

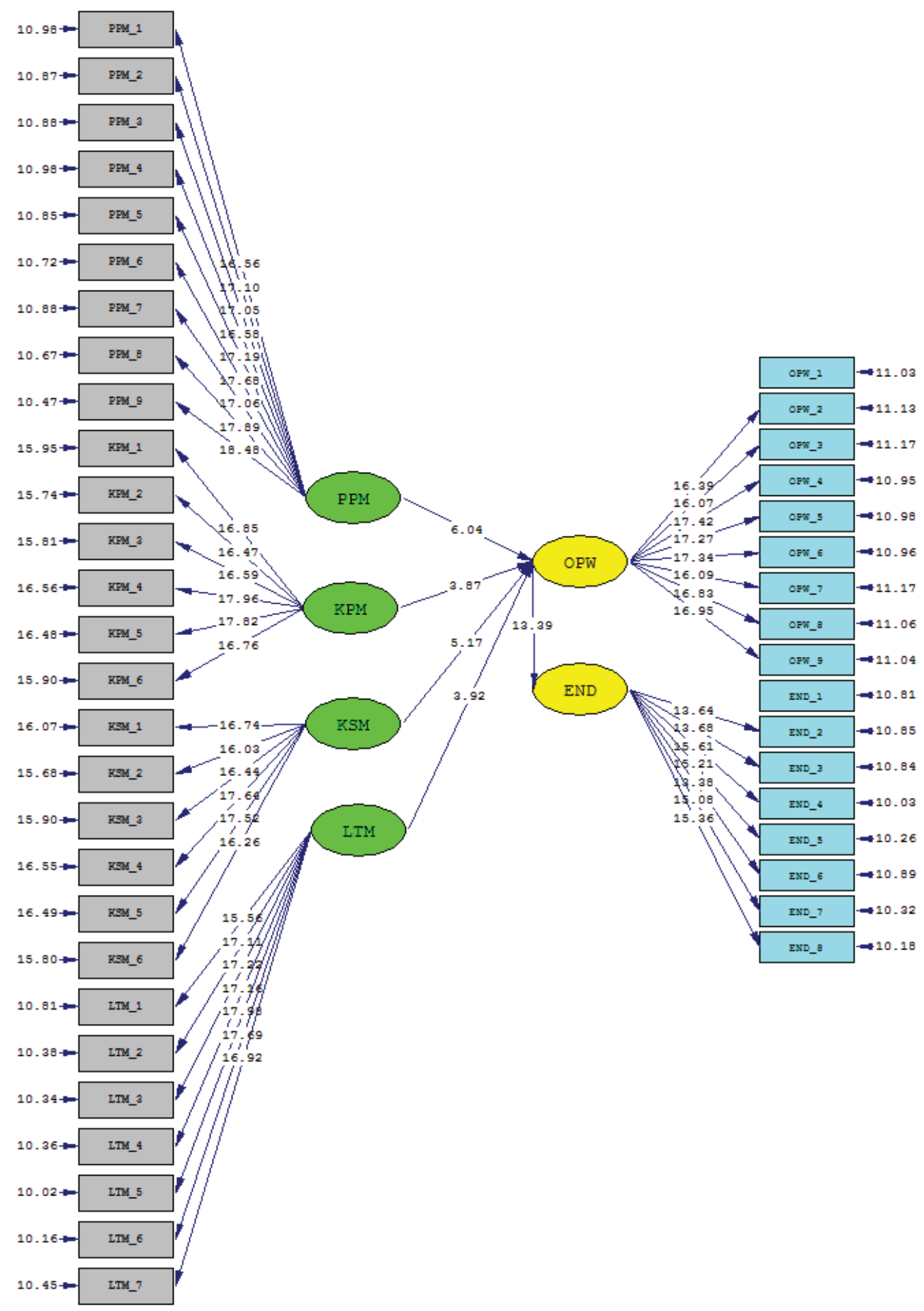

Chi-Square $=5027.85, \mathrm{df}=934, \mathrm{p}-\mathrm{value}=0.00000, \mathrm{RMSEA}=0.126$

Sumber: Data primer diolah, 2019. 
praktek. Taktik dan prosedur yang digunakan harus adaptif terhadap perkembangan teknologi. Taktik dan prosedur tersebut secara detail menjelaskan pengerahan kekuatan laut secara gabungan, metode deteksi dan penindakan, kepemimpinan, komando dan kendali, perencanaan dan pengambilan keputusan operasional, serta penggunaan fungsi-fungsi pendukung seperti intelijen, informasi operasi, logistik dan perlindungan. Taktik dan prosedur dalam pengendalian laut juga mencakup peperangan anti kapal permukaan karena sangat mungkin terjadi pelibatan terhadap kapal permukaan yang melakukan tindak pelanggaran baik hostile act maupun hostile intent. Taktik dan prosedur berikutnya yang harus dikuasai adalah prosedur tetap keamanan laut, aturan pelibatan, serta Visit, Board, Search and Seizure (VBSS). Selain itu, perlu juga penguasaan taktik dan prosedur dalam kerja sama taktis baik dengan kapal permukaan, kapal selam, pesawat udara dan dengan Pusat Komando dan Kendali (Puskodal). Penguasaan taktik dan prosedur juga mencakup pemahaman terhadap rencana operasi yang telah disusun, serta moril bertempur personel dalam menjalankan tugasnya."

Berdasarkan hasil pengujian terhadap hipotesis penelitian, sebagaimana terlihat pada gambar 2 dan gambar 3 menunjukkan bahwa pengetahuan taktik dan prosedur dalam melaksanakan pengendalian laut memiliki standardized coefficient 0,46 dan t-hitung 6,04 yang berarti bahwa variabel tersebut mempengaruhi secara signifikan dan positif terhadap efektivitas operasi dalam mendukung keberhasilan implementasi strategi pengendalian laut di ALKI II. Hal ini berarti bahwa semakin tinggi penguasaan taktik dan prosedur dari personel yang berdinas di KRI, pesawat udara maupun staf di jajaran Koarmada II, maka efektivitas operasi semakin baik dan pencapaian keberhasilan implementasi strategi pengendalian laut di ALKI II akan semakin tinggi.

\section{Pengaruh Kemampuan Persenjataan KRI (KPM) Terhadap Efektivitas Operasi (OPW)}

Salah satu fungsi operasi yang harus dipenuhi untuk mencapai efektivitas operasi adalah daya tembak atau kemampuan persenjataan (Wade, 2010:3-11). Daya tembak merupakan sarana yang efektif untuk pendekatan operasional yang bersifat ofensif dan defensive termasuk dalam melaksanakan pengendalian laut, pencegahan penggunaan laut dan penangkalan. Prioritas yang saat ini dikembangkan adalah pengembangan daya tembak gabungan terhadap sasaran militer di darat, permukaan laut, udara dan bawah permukaan laut. Dalam konteks pengendalian laut pada masa damai di ALKI II saat ini, kemampuan persenjataan dapat diukur dari variabel akurasi persenjataan, kemampuan menghancurkan sasaran permukaan, kemampuan peperangan anti kapal atas air dan peperangan asimetris, kemampuan VBSS, serta daya penggentar yang ditimbulkan terhadap pihak-pihak yang akan melakukan pelanggaran di ALKI II.

Berdasarkan hasil pengujian terhadap hipotesis penelitian, gambar 2 dan gambar 3 menunjukkan bahwa kemampuan senjata memiliki standardized coefficient 0,15 dan t-hitung 3,87 yang berarti bahwa kemampuan senjata mempengaruhi secara positif dan signifikan terhadap efektivitas operasi dalam mendukung keberhasilan implementasi strategi pengendalian laut di ALKI II. Dengan demikian, semakin tinggi 
kesiapan persenjataan yang dimiliki KRI selaku implementator strategi pengendalian laut di ALKI II, maka efektivitas operasi semakin baik dan pencapaian keberhasilan implementasi strategi pengendalian laut di ALKI II akan semakin tinggi.

Penggelaran kekuatan Koarmada II di ALKI II dihadapkan dengan derajat ancaman yang ada maka persenjataan yang dimiliki KRI dalam kategori mampu untuk melaksanakan penindakan (action) maupun bela diri (self defense). Kesiapan persenjataan merupakan bagian dari kesiapan operasional unsur sebagai bagian dari kesiapan operasional TNI Angkatan Laut yang merupakan kewajiban pokok Markas Besar Angkatan Laut (Mabesal) dibawah pimpinan Kepala Staf Angkatan Laut (Kasal) sesuai amanat Pasal 16 UU Nomor 34 Tahun 2004 tentang TNI. Kesiapan operasional ditentukan oleh tiga elemen yang membentuk formulasi kesiapan operasional yaitu material, personel dan tingkat pelatihan. Kesiapan peralatan termasuk persenjataan merupakan syarat mutlak berfungsinya suatu sistem alat utama sistem senjata (alutsista) maupun organisasi yang dipengaruhi oleh laju kerusakan, kemampuan pemeliharaan dan dukungan material. Untuk mendukung ketahanan alutsista TNI Angkatan Laut, diperlukan kemandirian dalam melaksanakan pembangunan, pengoperasian dan pemeliharaan alutsista tersebut (Nugraha, 2016:265).

\section{Pengaruh Kemampuan Sensor KRI (KSM) dan Pesawat Udara Terhadap Efektivitas Operasi (OPW)}

Network Centric Warfare (NCW) memiliki fokus pada kekuatan tempur yang dihasilkan dari hubungan yang efektif atau jaringan dari sistem peperangan (Albert, dkk.,
2005:7). NCW mendukung kecepatan komando sebagai konversi atas posisi keunggulan informasi menjadi aksi. Selanjutnya, NCW memiliki potensi untuk berkontribusi pada perpaduan dari tingkat taktis, tingkat operasional, dan strategis. NCW tidak secara sempit tentang teknologi, akan tetapi lebih luas tentang respon militer yang muncul di era informasi untuk memperoleh superioritas informasi diantaranya melalui keunggulan kemampuan sensor yang terintegrasi dengan sistem komando dan kendali. Kemampuan sensor yang memadai akan menunjang pencapaian efektivitas operasi mencakup radar udara, radar permukaan, radar navigasi, radar kendali senjata, dan peralatan deteksi bawah air. Kualitas sensor yang baik akan membantu proses pendeteksian, pengenalan dan penilaian terhadap suatu target, serta untuk memperoleh gambaran situasi udara, permukaan dan bawah air secara komprehensif dengan didukung pula dengan pertukaran informasi (info sharing) antar KRI, pesawat dan Puskodal.

Hasil pengujian hipotesis penelitian dapat diketahui bahwa kemampuan sensor memiliki standardized coefficient 0,15 dan nilai t-hitung 3,87 dengan demikian kesiapan sensor juga signifikan secara positif mempengaruhi efektivitas operasi. Berdasarkan hasil penelitian para responden berpendapat bahwa kesiapan sensor KRI dan pesawat udara merupakan salah satu faktor yang menentukan efektivitas operasi. Hal ini berarti bahwa bila kesiapan sensor KRI dan pesawat udara semakin baik maka operasi akan semakin efektif sehingga tingkat keberhasilan implementasi strategi pengendalian laut di ALKI II juga semakin tinggi. Untuk memperoleh gambaran situasi yang lebih lengkap maka penggunaan sensor KRI dikombinasikan dengan sensor dari pesawat udara. Penggunaan pesawat udara 
dalam metode pengawasan dikuatkan oleh pakar pertahanan laut Geoffrey Till seorang insinyur di Royal Naval College London dalam bukunya berjudul Sea Power yang mengajarkan bahwa untuk pengembangan angkatan laut dan teknologi pengendalian laut membutuhkan pesawat terbang (aircraft) early warning untuk pelaksanaan pengawasan (Till, 2004:125).

\section{Pengaruh Kuantitas dan Kualitas Latihan (LTM) Terhadap Efektivitas Operasi (OPW)}

Marcu dkk (2009:125) menyebutkan bahwa manpower is the essential military resource. Only with high quality and motivated people can budgets and weapon systems be turned into the effective military capablilites that are required to provide for a nation's security. Manajemen sumber daya manusia penting dalam mencapai pertahanan negara yang efektif dan mumpuni termasuk dalam penyelenggaraan operasi. Latihan merupakan elemen penting dalam membentuk sumber daya manusia professional sebagai bagian dari kesiapsiagaan operasional. Selanjutnya Vego (2016:67) menyebutkan bahwa keberhasilan suatu operasi sangat ditentukan oleh kualitas latihan dan tingkat kesiapsiagaan.

Latihan mencakup kerja sama operasi yang melibatkan berbagai elemen, latihan peperangan dan prosedur keamanan laut. Keberhasilan pengendalian laut tidak akan tercapai tanpa latihan yang memadai. Secara umum, latihan diperlukan untuk membangun kesamaan filosofi, bahasa operasi, maksud, serta mencapai kesatuan tindakan. Tingkat latihan satuan-satuan operasi TNI Aangkatan Laut merupakan integrasi antara material atau alutsista yang telah disiapkan dengan personel pengawak untuk dapat melaksanakan tugas-tugas operasi sesuai dengan fungsi asasi satuan tersebut dan tugas operasi yang akan dilaksanakan. Peningkatan profesionalisme perlu dilakukan melalui latihan yang komprehensif dan terprogram dengan baik. Komando Latihan (Kolat) yang dibentuk di masing-masing Komando Utama Operasional termasuk Kolat Koarmada II merupakan satuan yang menjadi penyelenggara utama penyiapan pelatihan operasional satuan sesuai dengan tingkat pelatihan yang diharapkan dan medan penugasan yang dihadapi. Pada tingkat Mabesal fungsi tersebut dilaksanakan oleh Dinas Operasi dan Latihan (Disopslatal) berkoordinasi dengan Komando Latihan dan Lembaga Pendidikan yang berkemampuan mendukung pelatihan operasional baik dalam bidang tenaga pelatih maupun fasilitas Pendidikan dan latihan.

Pelatihan operasional KRI dan pesawat udara termasuk latihan pratugas pengamanan ALKI II merupakan mata rantai pelatihan terintegrasi sebagai kelanjutan dari equipment training dan system integration training di KRI dan pesawat udara masing-masing. Hal itu juga menjadi bagian dari latihan bertingkat dan berlanjut mulai dari tingkat unsur di pangkalan (L1), latihan tingkat unsur dengan manuver lapangan/berlayar (L2), latihan antar unsur yang sejenis (L3) hingga latihan puncak TNI Angkatan Laut Armada Jaya, serta Latihan Gabungan TNI.

Efektivitas operasi tidak terlepas dari tingkat latihan yang dilaksanakan. Kaitannya dalam pengendalian laut di ALKI II, maka latihan dapat diukur melalui mekanisme latihan bertingkat dan berlanjut dengan materi mencakup latihan peperangan baik peperangan anti udara (PAU), peperangan anti kapal permukaan (AKPA), peperangan anti kapal selam (AKS), peperangan elektronika 
(Pernika) dan peperangan ranjau. Selain itu, diperlukan pula latihan dalam pengoperasian peralatan di kapal, latihan prosedur keamanan laut, latihan VBSS, latihan kerja sama taktis, serta latihan pratugas sebelum KRI dan pesawat udara berangkat untuk melaksanakan operasi di ALKI II.

Hasil pengujian terhadap hipotesis penelitian sebagaimana dapat dilihat pada gambar 2 dan 3 menunjukkan bahwa kuantitas dan kualitas latihan memiliki standardized coefficient 0,20 dan t-hitung sebesar 3,92 yang berarti bahwa kuantitas dan kualitas latihan mempengaruhi secara positif dan signifikan terhadap efektivitas operasi yang pada akhirnya akan menentukan keberhasilan implementasi strategi pengendalian laut. Berdasarkan hasil penelitian dapat diketahui bahwa semakin tinggi kuantitas dan kualitas latihan yang dilaksanakan maka operasi akan semakin efektif, serta keberhasilan implementasi strategi pengendalian laut di ALKI II semakin tinggi. Kondisi tersebut didukung keterangan informan dengan menyebutkan bahwa tingkat latihan yang memadai diperlukan untuk mencapai efektivitas operasi guna mendukung keberhasilan tugas. Latihan tersebut mencakup bentuk latihan pada saat pengadaan kapal baru dan kapal yang selesai melaksanakan perbaikan meliputi empat jenis pelatihan yaitu (1). Equipment course, personel belajar mempertanggungjawabkan penggunaan dan pemeliharaan secara teknis setiap peralatan yang ada di kapal. (2). System Integration Training, bagaimana antara satu peralatan dengan peralatan lainnya dapat saling mendukung untuk keberhasilan operasi. (3). Operasional training, integrasi antara peralatan dengan manusia sebagai pengawak dihadapkan dengan misi yang diemban. (4). Shut Down Training, Work Up period, latihan ini didesain untuk mencapai standar yang diharapkan guna menghadapi kontijensi termasuk perang.

\section{Pengaruh Efektivitas Operasi (OPW) Terhadap Keberhasilan Koarmada II Dalam Mengimplementasikan Strategi Pengendalian Laut Pada Masa Damai di ALKI II (END)}

Pengendalian laut merupakan sarat utama terwujudnya keamanan jalur transportasi laut serta dukungan terhadap kekuatan yang berada di darat sehingga turut menentukan keberhasilan kegiatan di darat. Dengan demikian, pengendalian laut merupakan syarat kebangkitan dan keberlangsungan suatu bangsa. Keberhasilan dalam melaksanakan pengendalian laut sangat ditentukan oleh efektivitas operasi yang terkait dengan penyebaran pangkalan, penyebaran KRI dan pesawat udara sesuai dengan prioritas ancaman untuk memberikan kebebasan bertindak dan multiple short lines of operation. Selanjutnya Wade (2010:2-11) mengemukakan bahwa penyelenggaraan operasi yang efektif harus memperhatikan enam fungsi operasi yaitu komando dan kendali (command and control), daya gerak dan akses (mobility and access), daya tembak (fire power), ketahanlamaan operasi (sustainment) dan proteksi (protection).

Efektivitas operasi sangat diperlukan dalam melaksanakan pengendalian laut. Beberapa faktor penting sebagai indikator (variabel teramati) dalam penyelenggaraan operasi yang efektif meliputi gelar pangkalan yang mendukung untuk memperpendek rantai logistik, penyebaran KRI dan pesawat udara sesuai dengan prioritas ancaman, kecepatan dalam merespon terhadap tindak pelanggaran hukum di laut, interoperabilitas antar matra TNI dan dengan instansi maritim 
lainnya, pemahaman terhadap rencana operasi, kesiapsiagaan operasi, daya tangkal yang dapat dibangun, serta pemahaman prosedur pengendalian laut dan pencegahan timbulnya kecelakaan personel maupun materiil di pihak sendiri. Keberhasilan pengendalian laut sendiri ditentukan oleh beberapa faktor yakni kemampuan monitoring penggunaan ALKI II (superioritas informasi), kemampuan melaksanakan penindakan terhadap berbagai pelanggaran sesuai dengan kewenangannya, daya tembak untuk perlindungan diri maupun melumpuhkan kekuatan lawan, pengendalian internal unsur-unsur yang melaksanakan operasi, interoperabilitas, daya tangkal untuk mencegah niat lawan melakukan pelanggaran, terlaksananya rencana operasi, serta terciptanya rasa aman bagi para pengguna laut untuk memanfaatkan ALKI.

Berdasarkan hasil penelitian dapat diketahui bahwa efektivitas operasi yang diselenggarakan sudah baik. Hasil pengujian terhadap hipotesis penelitian, menunjukkan bahwa efektivitas operasi memiliki standardized coefficient sebesar 0,87 dan t-hitung sebesar 13,39 yang berarti bahwa efektivitas operasi berpengaruh secara positif dan signifikan terhadap keberhasilan Koarmada II dalam mengimplementasikan strategi pengendalian laut di ALKI II. Hal tersebut memiliki maksud bahwa semakin tinggi efektivitas operasi yang digelar oleh Koarmada II, maka pencapaian keberhasilan implementasi strategi pengendalian laut adalah keniscayaan. Efektivitas operasi tersebut dipengaruhi oleh variabel laten yakni penguasaan terhadap taktik dan prosedur, kesiapan persenjataan, kesiapan sensor, serta kuantitas dan kualitas latihan yang dilaksanakan.

Dalam strategi pengendalian laut di ALKI II, kekuatan Koamada II mempunyai dua hal pokok yakni penyebaran kekuatan (deployment) dan pengerahan kekuatan (employment). Penyebaran kekuatan berkaitan dengan penempatan kekuatan pada titik-titik strategis secara permanen dalam rangka mendukung kebutuhan taktis dan strategis dari upaya pengendalian laut. Pengerahan kekuatan berkaitan dengan penggunaan kekuatan pada periode tertentu pada lokasi atau area strategis terhadap ancaman nyata maupun potensial. Sebagaimana teori ancaman, untuk memberikan dampak penangkalan maka penggelaran kekuatan harus dapat menunjukkan kehadiran sepanjang waktu di wilayah yang dikuasai atau dikendalikan tersebut. Kehadiran sepanjang waktu merupakan upaya komunikasi intensi secara langsung yang diharapkan mampu memberikan dampak penangkalan. Kehadiran unsur di laut yang terlihat oleh pengguna khususnya keberhasilan dalam melaksanakan penindakan terhadap aktor-aktor pelaku pelanggaran di ALKI II akan memberikan dampak penangkalan sehingga mencegah niat pengguna laut untuk melakukan tindak pelanggaran.

Penggelaran penindakan yang dilaksanakan oleh Koarmada II dengan kekuatan yang ada untuk menghadapi kejahatan di ALKI II dengan didukung pangkalan yang berada di Surabaya, Banyuwangi, Bali, Mataram, Kotabaru, Banjarmasin, Makassar, Mamuju, Balikpapan, Palu, Tarakan, ToliToli, Nunukan sebagai pangkalan aju untuk unsur-unsur pemukul strategis seperti Frigate, Corvette, Kapal Cepat Torpedo (KCT), Kapal Cepat Rudal (KCR) dan Fast Patroli Boat (FPB). Pola operasi disusun berdasarkan pola rotasi (employment cycle) yang fleksibel. Susunan penggunaan kekuatan secara ideal terdiri atas tiga bagian yaitu unsur yang melaksanakan operasi, unsur standby dan unsur perbaikan. Pola ini dapat berubah sesuai 
dengan kebutuhan penggelaran menjadi dua yakni unsur operasi dan unsur perbaikan sesuai dengan tuntutan kebutuhan kehadiran di laut yang berdasarkan ekskalasi dan prioritas ancaman.

Berdasarkan ancaman yang ada maka dibutuhkan pengumpulan data dan informasi intelijen yang berasal dari berbagai sumber baik operasi intelijen oleh satuan intelijen Koarmada II maupun dari satuan samping termasuk informasi dari masyarakat pesisir dan nelayan. Berkaitan dengan pola penggelaran kekuatan di ALKI II maka pola penggelaran yang dilakukan adalah dengan meningkatkan intensitas operasi pengamanan ALKI II di ujung utara ALKI II termasuk dengan wilayah perairan perbatasan dengan Malaysia dan Filipina dengan meningkatkan penggunaan KRI yang memiliki daya tangkal tinggi dan daya tahan laut yang optimal untuk kondisi di Laut Sulawesi.

Implementasi strategi pengendalian laut memerlukan kombinasi penggunaan unsur permukaan dan unsur udara. Unsur permukaan menerapkan pola operasi tunggu pada lokasi atau titik strategis terdekat dengan area patroli dan bergerak berdasarkan informasi sasaran yang ditemukan oleh Puskodal, intelijen dan unsur pesawat udara yang sedang melaksanakan patroli. Pola gerak pesawat udara sangat ditentukan oleh informasi dari Puskodal dan intelijen. Dengan pola operasi tersebut, pola gerak unsur permukaan dan unsur udara dapat diefektifkan untuk menunjang keberhasilan implementasi strategi pengendalian laut. Selain itu, efektivitas operasi juga didukung oleh Second Fleet Quick Response yang berada pada pangkalan-pangkalan TNI Angkatan Laut di sepanjang ALKI II dengan tugas pokok melaksanakan aksi cepat penindakan dalam rangka preventif maupun represif terhadap suatu laporan kejadian, serta standby 1×24 jam untuk mengantisipasi distress signal suatu laporan hasil analisa Puskodal Koarmada II. Penempatan satuan reaksi cepat tersebut bersifat fleksibel di tiap-tiap pangkalan sesuai dengan hotspot kerawanan yang menjadi prioritas.

\section{SIMPULAN}

Berdasar penjelasan tersebut di atas dapat ditarik simpulan sebagai berikut.

Pertama, ketahanan nasional Indonesia sebagai negara kepulauan tidak terlepas dari kemampuan mewujudkan stabilitas keamanan maritim di antaranya melalui pengendalian laut di ALKI II.

Kedua, keberhasilan Koarmada II dalam melaksanakan pengendalian laut ditentukan oleh beberapa faktor determinan dalam mengimplementasikan strategi pengendalian laut di ALKI II yaitu (1). Penguasaan taktik dan prosedur dalam pengendalian laut memilili koefisien path 0,46 dan t-hitung 6,04, sehingga penguasaan taktik dan prosedur dalam pengendalian laut berpengaruh secara positif dan signifikan terhadap efektivitas operasi. (2). Kemampuan persenjataan KRI memiliki koefisien path 0,15 dan t-hitung 3,87, sehingga persenjataan KRI berpengaruh secara positif dan signifikan terhadap efektivitas operasi. (3). Kemampuan sensor KRI dan pesawat udara memiliki koefisien path 0,19 dan t-hitung 5,17, sehingga kemampuan sensor KRI dan Pesawat Udara berpengaruh secara positif dan signifikan terhadap efektivitas operasi. (4). Kuantitas dan kualitas latihan memiliki koefisien path sebesar 0,20 dan t-hitung sebesar 3,92, sehingga kuantitas dan kualitas latihan yang dilaksanakan secara terpadu, bertingkat dan berlanjut berpengaruh secara positif dan signifikan terhadap efektivitas 
operasi. (5). Efektivitas operasi memiliki Koefisien path sebesar 0,87 dan t-hitung sebesar 13,39, sehingga efektivitas operasi berpengaruh secara positif dan signifikan terhadap keberhasilan Koarmada II dalam mengimplementasikan strategi pengendalian laut pada masa damai di ALKI II.

Selanjutnya, peneliti merekomendasikan hal-hal sebagai berikut.

Pertama, perlunya penelitian ini dapat dikembangkan untuk(1). Menganalisis efisiensi dalam implementasi strategi pengendalian laut di ALKI II pada aspek operasi, serta optimalisasi pada aspek komando dan kendali. (2). Menganalisis pengaruh ketersediaan sarana prasarana navigasi yang memadai di sepanjang ALKI II, serta pemberlakuan Traffic Separation Scheme (TSS) di Selat Lombok dalam mendukung keberhasilan strategi pengendalian laut di ALKI II.

Kedua, pengendalian laut harus terlaksana dengan baik sebab merupakan syarat terwujudnya stabilitas keamanan maritim sebagai penopang ketahanan nasional Indonesia sebagai negara kepulauan.

\section{DAFTAR PUSTAKA}

Albert, dkk., 2005, 'Network Centric Warfare, Developing and Leveraging Information Superiority', Washington DC: CCRP Publication Series.

Buntoro, Kresno, 2017, 'Nusantara ALKI (Alur Laut Kepulauan Indonesia)', Depok: PT Rajagrafindo Persada.

Creswell, John W., 2016, 'Research Design Pendekatan Metode Kualitatif, Kuantitatifdan Campuran', Yogyakarta: Pustaka Pelajar

Djalal, Hasyim, 2010, 'Negara Kepulauan Menuju Negara Maritim', Jakarta: Lembaga Laut Indonesia.
Hidayat, Abdiyan Syaiful, 2019, 'Analisis Determinan Keberhasilan Koarmada II Dalam Mengimplementasikan Strategi Pengendalian Laut Pada Masa Damai di ALKI II Menggunakan Metode Structural Equation Modeling (SEM)', Tesis, Perwira Mahasiswa Dikreg Seskoal Angkatan Ke-57 TP. 2019.

Marcu, dkk., 2009, 'Defence Management: An Introduction', Geneva: Procon Ltd. Marlina, Diane, 2009, 'Structural Equation Model Untuk Industri Musik Online di Indonesia', Thesis, Universitas Indonesia Fakultas Teknik Program Studi Teknik Industri.

Nelson, C. Richard, 2016, 'The life and work of General Andrew J. Goodpaster : Best Practices in National Security Affairs', Amerika Serikat.

Nugraha, 2016, 'Studi kelayakan PT PAL Indonesia (PERSERO) Dalam Pembangunan Kapal Perusak Kawal Rudal (PKR) Guna Mendukung Ketahanan Alutsista TNI AL', Journal Ketahanan Nasional, vol 22, no 3, hh. 255-266.

Sobaruddin, Dyan Primana, 2017, 'Model Traffic Separation Scheme (TSS) Di Alur Laut Kelupauan Indonesia (ALKI) I Di Selat Sunda Dalam Mewujudkan Ketahanan Wilayah', Journal Ketahanan Nasional, vol 23, no. 1,hh. 104-122

Suryohadiprojo, Sayidiman, 1997, 'Ketahanan Nasional Indonesia', Journal Ketahanan Nasional, II(1), hh.14.

Till, Geoffrey, 2004, 'Sea Power', Frank Cass, London Portland.

Vego, Milan N., 2016, 'Maritime Strategy and Sea Control: Theory and Practice', London:Routledge. 
Wade, Norman M., 2010, 'The Naval Operations and Planning Smart Book, Guide to Designing, Planning and Conducting Maritime Operations', Lakeland: The Lightning Press.

Wahyono, S.K., 1996, 'Strategi Pertahanan Laut Dalam Rangka Ketahanan
Nasional', Journal Ketahanan Nasional, vol 1, no 1, hh. 23.

\section{Peraturan Perundangan}

Undang-Undang Nomor 34 Tahun 2004 tentang Tentara Nasional Indonesia.. 